New Zealand Journal of Industrial Relations, 19(1): 85-101

\title{
COMMENTARY
}

\section{The Impact of the Employment Contracts Act on Labour Law: Implications for Unions}

\section{Walter Grills*}

The Employment Contracts Act 1991 (the ECA or the Act) is only one of a number of fundamental changes to the basis upon which New Zealand society has recently been required to operate. These changes have been thrust upon New Zealanders by successive governments. The response of the people to such forced feeding has been to change the very basis of how governments are to be elected and are to operate. The public complaint is not only with the fast pace of unanticipated and undesired change. The complaint is more with the failure of politicians once elected to carry out policy announced in the process of electioneering.

However, one example of an election promise fulfilled, and a fundamental change force fed, is the Employment Contracts Act. The ECA is not only about the efficiency of the labour market, but the accountability of employees to their employers. The fundamentals of the Act were set out in the National Party's election manifesto. The National Party won the 1990 election by a substantial majority. Pat Walsh and Rose Ryan describe the speed and determination of the Government as follows:

\footnotetext{
On 9 November, still less than a fortnight after the election, the Minister of Labour sent a paper to the Cabinet meeting of i2 November seeking authorisation for legislation to repeal exclusive membership and negotiating coverage for registered unions, to introduce voluntary unionism, to allow employers and employees to 'freely determine their own arrangements for establishing, conducting, settling and enforcing the outcome of negotiations', and to ensure that collective settlements had the status of binding contracts enforceable in a court of law. (Harbridge, 1993:18)
}

The change to the law effected by the ECA was both abrupt and radical. The question which this paper addresses is, "What is the impact of the ECA on labour law?" The short answer to the question may be given in one sentence. The primary impact of the ECA on labour law is to abolish the legal status accorded to the trade union movement for the previous 97 years.

\footnotetext{
Walter Grills is an Adjudicator and Mediator Member of the Employment Tribunal in Dunedin. The views expressed are the personal views of the author. He is grateful to Bronwen Morris, Susan McBride and Dianne Marsh for assistance in the preparation of the paper, and to Ian McAndrew for editorial comments. An earlier version of the paper was presented to a seminar on Employment Law sponsored by the New Zealand Institute of Industrial Relations Research in October, 1993
} 


\section{The Council of Trade Unions: its political and legal status}

The new law impinges not only upon the status of individual unions, but also upon the central organisation of trade unions. Private and public sector unionists have long been represented through central organisations which have been recognised and consulted. More recently these organisations have joined together in the New Zealand Council of Trade Unions (CTU). Organised labour had historically been treated as a part of a partnership with the government, the central organisation of private sector employers, and the State Services Commission. Successive governments and their laws accorded special status to the central organisation of employees. Both the Labour and National Parties in government took a tri-partite approach which involved the union movement to a greater or lesser extent in the management of the economy.

The policy of the previous National Government included consultation with the Federation of Labour. In 1984 agreement was reached with the trade union movement on a number of significant reforms to the wage fixing system. One reform included a provision for tripartite conferences to be held each year prior to the commencement of a wage round. The initial purpose of the conference was for the government to brief the parties on the state of the economy, and for the parties to state their views as to the appropriate approach to bargaining within the wage round. The position of the lower paid worker was also considered not only in respect to wages, but to other social benefits. However, wage guidelines, or the appropriateness of such guidelines, were subjects which were seldom agreed upon. The conferences allowed the government to talk down union expectations, the employers to cry poverty, and the union movement to be seen in the eyes of its membership as a major player in the management of the economy. If the tri-partite wage conference failed to achieve its own objectives, then at least from the union movement's perspective, the tri-partite conference was a good public relations exercise. Within the legal confines of the tri-partite wage conference, disagreement rather than cooperation characterised the relations between governments and the central organisation of workers. Nevertheless, the Labour government succeeded in 1989, as the National government had in 1984 , in reaching an accord of sorts with the union movement.

In December 1989, the CTU reached an agreement, known as "the Compact", with what was to be the outgoing government in October of the following year. The cynical would describe the Compact as a political diversion. The former Prime Minister, David Lange, had stepped down following an embarrassing split with the Minister of Finance over a flat tax proposal and the pace forced by the government in completing its conservative economic reforms. The Compact was designed to show a unity which the party clearly did not enjoy. Nevertheless, the Compact was, in principle, significant. The Compact was concerned with consultative processes. Agreement was reached between the government and the CTU on broad principles of consultation both between the unions and the government, and between unions and employers at the workplace. Significantly, the Compact was a bi-partite agreement. The employers' central organisations were by that time no longer interested in centralised consultation. Employers were not party to the Compact. The New Zealand Business Roundtable (NZBR) and the New Zealand Employers Federation (NZEF) had overcome any differences between them and were 
designing the shape of the National Party's Employment Contracts Bill. By the time of the last tri-partite conference in August 1990, the NZEF was critical of the forum, and did not see it as appropriate to the decentralised wage fixing system it was now advocating. The last tri-partite wage conference was adjourned to await the outcome of the election.

The adjournment of the tri-partite conference marked the faltering status of the union movement. The election in October 1990 resulted in the defeat of the fourth Labour government, and signalled the death knell for the Compact. Hence, the union movement's fall from grace was sudden and the slope was steep. On one side of the election, the trade union movement had sufficient status to be a party to a Compact with the government described by the then Prime Minister, Jeffrey Palmer, as "a significant step forward in developing new ways for the social partners to work together for a better future." On the day before the election, the union movement had a role in which it could potentially affect the future social and economic progress of the country. Less than two weeks after the election the headlines in The Dominion newspaper announced "PM Hedges On Accord".

The Government did not commit itself on the Compact. It drafted the Employment Contracts Bill with the assistance of an employee of the Wellington Employers Association, and put the aspects of the Bill which directly affected the union movement into effect without genuine consultation with the unions. Immediately following the election, not only was the Compact abandoned, but the labour law as it provided for tri-partite wage fixing and the recognition of the central organisation of employees, was abolished. The failure of tri-partite provisions of the Labour Relations Act 1987 (the LRA) had for some time been apparent, and to this extent the abolition of the tri-partite approach was of little practical significance to labour law. Nevertheless, it was of major symbolic significance. The demise of a century old tradition of centralised wage fixing corresponded with the demolition within labour law of the status of the central organisation of trade unions. But the statutory bums-rush was directed, not only at the central organisation of the trade union movement, but also against its constituent membership.

\section{Disorganising organised labour}

The LRA of 1987 provided for a form of compulsory union membership. It required the insertion of a standard clause, the unqualified preference clause, in all awards and agreements where employers and unions agreed to its insertion. The standard clause provided that employees were required to join the union within 14 days of being requested to do so by the union. If the employer party and the union did not agree, a ballot was conducted. The standard clause was not inserted unless a majority of the covered employees voting voted in support of its insertion. This arrangement was decided upon after a series of legislative experiments with different types of union membership provisions. The National government had introduced voluntary unionism effective February 1984. Voluntary unionism cut deeply into union membership. In 1985 the Labour government again changed the legislation. The unqualified preference provision was required to be in every award and agreement. And this was again modified by the LRA in 1987. As noted, the unqualified preference clause was now to be inserted either by agreement or by ballot. 
The ECA reintroduced voluntary unionism. In essence under the ECA, contracts cannot require, and unionists cannot behave in a way which coerces employees to join a union. Voluntary unionism can always be expected to decrease union membership, but its effects under the ECA can be expected to be more severe than in 1984. This is because the ECA combines voluntary unionism with a number of other barriers to the organisation of labour which did not accompany voluntary unionism as it was introduced in 1984.

\section{Access to workers}

Under the LRA, the union was an original party to the award and, as a body corporate, had a direct legal interest in the award's administration and a right of access to the workplace. Formerly, Labour Department inspectors were charged with enforcing awards. Under the LRA the government had decided that enforcement should become a private matter, and the role was assigned to union officers and paid officials. Unions were given right of access at reasonable times to interview employees where there were reasonable grounds for believing that an award was not being adhered to. The union official also had powers both to investigate wage records and to interview the employer. Similarly, access was provided to union officers and paid officials to carry out union business, such as requesting that employees become members of the union, collecting subscriptions, and collecting information as to ballots. The LRA also provided for two paid stop work meetings per year. Finally, the LRA stipulated that the employer was to provide unions with the names, addresses, and work classifications of employees covered by awards. Hence, the LRA contained substantial advantages for organising a union. Employers were required by law to allow union officials access to records for the purpose of award enforcement, and also for signing up members. The latter was facilitated by the requirement that the employer was to provide on a six monthly basis checklists of current employees so that the union could identify potential members.

Under the ECA the door has been shut in the union's face, and is not to be opened unless the employer says so. The Act provides that a potential representative may enter the work place, but only by agreement of the employer. If the employer does not agree, then a union cannot approach potential members while they are at work. The difficulties in influencing employees to join the union when they are not at work are apparent. The message about joining the union could be conveyed to a group of 40 potential unionists at a single onehour meeting at the workplace. Conveying the same message on an individual basis away from the workplace might take 40 hours. A general meeting could be organised outside of work hours, but many workers do not want to be seen as conspiring against their employer. It is somewhat analogous to appearing as a witness before the Employment Tribunal. Workers don't mind giving evidence if they are summoned, but they do not want to be seen as voluntarily testifying against their employer. Under the LRA employees were in a sense "summoned" by compulsory union membership provisions to be union members. No employee stood out as anti-employer by virtue of joining the union.

The ECA does provide a right of access for a duly authorised representative of an employee to enter the workplace at reasonable times to discuss the negotiation of a contract. This right of access presupposes, however, that the union has been able to organise the 
workforce in the first place. In many, if not most circumstances, the union is likely to fail to initially organise the workforce without access to the workplace. The union suffers the decided disadvantage that the employer has, while his employees are at work, a captive audience. Where a union had been solidly organised under the LRA, access will be granted by virtue of the force of that solidarity. Where the organisation had been loose, and employees were union members only because of compulsory unionism, the access provisions of the ECA will usually preclude effective union organisation of the workplace.

\section{The legal status of unions}

The term "union" is conspicuously absent from the ECA. The Act is essentially silent as to how a union and an employer are to treat one another during collective bargaining. Section 185 (1) does refer to unions, but only for the purpose of deeming unions which were formally registered under the Labour Relations Act to be registered under the Incorporated Societies Act 1908. The trade union therefore is like any other group of persons joined for purposes other than pecuniary gain, and incorporated under the Incorporated Societies Act. However, the absence of the term "union" from the Act is more than just a political snub or legal slight. Under the LRA, a registered union had automatic bargaining rights in respect of employees who performed work that fell within the scope of the union's membership rules. The union was most often the applicant for a new or renewed award, and was therefore an original party to the award.

Under the ECA a union has no particular status. Its registration under the Incorporated Societies Act does not convey bargaining status upon a union. A union must have received authority to bargain on behalf of employees from the employees themselves. Hence, the union does not have original party status in the sense that the union is the initiator of negotiations for new or renewed contracts. The "original" parties to an employment contract are employers and the employees. Once an individual or collective contract is settled, then the representative may be a party to the contract with the consent of the other parties. That representative might be a union, or it might be a lawyer or industrial advocate or consultant. The advantage to a union and its membership in the union being a party to the contract is that the union can enforce the contract, and agree to or veto a variation of the contract during its currency.

On the other hand, a union becoming a party to a contract could potentially become the subject of an action for damages where the contract is breached. This may be particularly important in the case of an illegal strike, such as a wildcat strike carried out by a small sector of workers without the approval of the general membership. Therefore, there may be some disadvantage to a union in being a party to a collective contract. In any event a union finding it a necessity to take an enforcement or compliance action during the currency of a contract is likely to have negotiated the collective contract with an employer of sufficient hostility to refuse to allow the union to be a party to the contract. The experience thus far under the ECA has been that there is some considerable resistance to unions becoming parties to collective contracts. Unions have succeeded in doing so only in approximately 25 percent of collective contracts (Harbridge, 1993:74). 


\section{Standing before the Employment Court and Tribunal}

A union is an incorporated society for whatever purposes the union's rules stipulate. However, the union has only the potential status of a representative under the ECA to represent its membership before the Employment Tribunal or Employment Court. Registration under the LRA gave the union the automatic right to represent its membership. A union's standing before the former Mediation Service and Labour Court was seldom challenged. No such automatic right to represent its members exists for a union under the ECA. Section 59 provides that an employee may choose to be represented in order to exercise general rights established under the Act. But it does not automatically follow that an employee has given the union authority merely because the person is a member of the union.

A set of union rules providing that the union shall be a representative in any or all possible legal actions under the ECA may be in conflict with the Act itself. Subsection 59 (3) provides that "Any person purporting to represent any employee or employer shall establish that person's authority for that representation". This section speaks of employee in the singular, and not of employees collectively. The word "that" emphasises the individual person and a particular representation. In Ward $v$ Christchurch Transport [(1992] 1 ERNZ 306), despite an employee signing a general authority for the union to act on behalf of the employee, the evidence demonstrated that the particular employee did not want to join other employees as an applicant in the particular proceedings. While the possibility remains that the Court may under certain circumstances accept that a "class action" by one or a relative few employees on behalf of a general class of similarly placed employees is appropriate, it appears that that will be the exception under the ECA, not the rule. The onus is on the union, as representative, to convince the Court of the appropriateness of the approach (see United Food etc Union of NZ v Talley [1992] 3 ERNZ 423).

In Adams v Alliance Textiles ([1992] 1 ERNZ 982) the union sought to have a collective contract set aside, but could not convince sufficient union members to give their authority to proceed with the case have the collective contract set aside in its entirety. The Employment Court considered the merits of the case only insofar as the collective contract applied to those who had given authority to the union to run the case. The Chief Judge emphasised the importance of having clear individual authorities from employees. The difficulty from the union point of view is that individual employees do not wish to reveal their opposition to an aggressive employer, particularly during times of high unemployment. The difficulty for the Tribunal or the Court is that there is no evidence either way. On the face of the Alliance case, the workers may have been intimidated, or they may simply have been happy with the collective contract.

\section{Unions as bargaining agents}

The idea that the union can act on its own authority is severely limited under the ECA. That is because the union must be a party to a collective contract in order to appear before the Employment Tribunal or Employment Court on an enforcement matter, and employers are reluctant to agree to unions being party to their collective contracts. The limitations 
also extend to collective bargaining. Section 10 of the Act establishes the right of employees to be represented in the negotiation of their employment contracts. Section 12 pertains specifically to the authority needed by unions and other bargaining agents to represent employees in the negotiation of employment contacts. Subsection 12 (1) requires that the representative establish its authority. Ideally, the representative will have an authorization signed by the employee or employees. The significance of the impact of this section should not be overlooked.

Under the LRA, negotiators were nominated by cited parties to an award. The Act did not specify nomination procedures, and required the mediator convening the conciliation council to simply be satisfied that the nominated negotiators were representative of the industry. The practice was that the mediator asked the negotiators if they were representative of the industry, and then accepted their assurances that they were. Objections of various kinds were occasionally heard. But in the vast majority of award negotiations under the LRA, examination of the question of representation was cursory, if not farcical. An award agreed upon most obviously bound the cited employer parties and their employees. But the award was also binding on all other employers, known as subsequent parties, and their employees throughout the industry. By virtue of the provisions of the LRA, and the award's coverage clause, the award bound all employers in the industry without their consent. The award also bound their employees without their consent. The award was negotiated by negotiators who simply did not ask for, and were not given the individual authority of employers and employees to act on their behalf.

Subsection 12 (1) of the ECA makes it clear that the law has been reversed. The irony of the LRA was that negotiators were not required to have direct authority to represent individual employees or employers, yet it was a requirement that award negotiators have legal authority to reach binding agreements without first referring the agreement back to those who were to be bound by it for their approval. Section 16 of the ECA pertains to the ratification of settlements where a contract is negotiated by an authorised representative. A ratification procedure must be agreed prior to negotiations, and a settlement must be ratified if the agreement is to become a binding employment contract.

\section{Discriminating against unionists}

The union does not act on its own behalf as a collective or body corporate, but as a representative of its members. The union is treated under the Act as no more or less than a lawyer or industrial advocate. The point is of importance not only because of the administrative difficulties involved in obtaining individual authorities for large numbers of union members, but also to illustrate that the ECA treats the question of union membership as an issue different from that of the union's role as a representative. The right to union membership does not mean the same thing as the right to have your union representative recognised in the sense of being dealt with fairly or in good faith. An employer can actively discourage employees use of a representative, and actively encourage the employees to abandon their representative. The employer can take up any or all of these tactics without being said to unduly influence the employees in respect to union membership. 
Sections 6 and 7 of the ECA establish that membership of employee organisations is voluntary, and preference in employment or in regard to conditions of employment shall not be based on union membership or non-membership. However, as the Chief Judge's analysis reveals in Adams $v$ Alliance Textiles, while the employer must remain neutral in respect to an employee joining or not joining a union, the employer does not have to remain neutral as to whether the employee utilises the union as a representative in collective bargaining. Sections 6 and 7 are about membership in unions and clauses in contracts. They do not prescribe how an employer should treat representatives of employees.

Section 8 of the Act may appear at first sight to have more application. In part, Section 8 refers to the protection of individual representatives, including union representatives, from undue influence directed at encouraging them to not act or to cease acting on behalf the employees they represent. Even so, nowhere in this section does it prohibit an employer approaching the employer's own employees in an effort to discourage the engagement of a union representative or the continued use of a union representative in negotiations.

\section{Union recognition}

Section 20 (3) of the ECA provides that the employer, in negotiating a collective contract, may negotiate with either the individual employees or any authorized representative of the employees. Whether the employer deals with individual employees or a union representative is over to the employees. Section 21(1)(b) stipulates that in negotiating a collective employment contract, the employer may negotiate with the employees themselves or "(i)f the employees so wish, any authorized representative of the employees." This section is reinforced by Section 12 (2), which says that the employer must recognise the authority of a duly authorised representative of employees for the purpose of negotiating an employment contract. The section does not distinguish between individual and collective employment contracts, and therefore a representative must be recognized for the purpose of negotiating either a collective or an individual contract of employment.

The section does not define the meaning of "recognize". However, Adams v Alliance Textiles does provide a definition of what recognition is not, or at least what recognition does not require. According to the Chief Judge, recognition does not require that the employer negotiate with the union. Nor does it prevent the employer from approaching employees directly with the intention of persuading them to abandon the union as their authorized representative and negotiate a collective contract directly with the employer. The Act, therefore, provides for limited recognition of an authorised union in the sense that employees can, under Section 20 (3) (b), insist on the employer bargaining with their representative if the employer wants to bargain over a contract. Of course, the employer need not continue to pursue a collective contract, because Section 18 (1) (a) provides that the parties are free to negotiate "(t)he question of whether employment contracts are to be individual or collective."

An employer may simply refuse in negotiations to negotiate a collective contract. The employer has to recognise a union representative's authority to negotiate a collective 
contract, but the employer doesn't have to negotiate such a contract. Section 8 of the ECA does not prohibit the employer directly approaching the employees about the advantages to them of negotiating directly with the employer and of revoking the authority previously given to their representative (or, indeed, the advantages of withholding authority and dealing directly with the employer in the first place). In short, nothing in the Act requires the employer to remain neutral in respect to influencing employees attitudes towards utilising or not utilising a bargaining representative. The employer, therefore, may at any time seek to convince the employee to revoke a bargaining authority, to abandon his or her bargaining agent, and to bargain directly with the employer over a collective contract. Hence, union recognition can be thwarted by the employer's refusal to negotiate a collective contract, or by the employer's persuasion of employees to revoke the union's bargaining authority.

The wording of the ECA simply does not say that the employer must recognise the representative in the sense of honourable dealings or negotiations in good faith. To the contrary, in Adams $v$ Alliance Textiles, while initially accepting that the union would be party to a collective agreement, the company ultimately encouraged the employees to seek alternative advice. The company convinced employees either that the union was not acting in their best interests, or that they had no alternative but to sign contracts to which the union was not a party and of which union officials did not approve. The company was negotiating at two plants, one at Redruth and the other at Mosgiel. The Court found that the company secured agreement with a single delegate at Redruth and agreed to keep that agreement secret. The delegate did not have authority to negotiate on behalf of other employees, and the union was not party to the contract which the individual delegate signed. The company then announced to the Mosgiel workforce that agreement had been reached at Redruth on a contract that excluded the union. Employees then began signing up at both plants and the union was defeated. On the significance of the requirement to recognise a bargaining agent, Chief Judge Goddard of the Employment Court had this to say in Adams $v$ Alliance Textiles:

It is clear that the respondents did recognise the authority of the union to represent the applicants. So much so that they require the applicants to withdraw their appointment of the union as their representative as a condition of signing the contract personally. The contract referred to is the contract which excluded the union as a party

However, the judgement of the Employment Court in Adams vs Alliance Textiles was appealed. The Court of Appeal heard the case, but declined to decide the issues raised on the grounds that the issues were no longer alive. Nonetheless, in reaching this conclusion, the Court made a number of instructive comments which are of persuasive rather than precedential force. The Court expressed reservations about one aspect of the Employment Court decision. That aspect related to union recognition. The President of the Court of Appeal said:

As I understand the relevant passage in the judgement of Chief Judge Goddard reported in [1992] 1 E..R.N.Z. at 1023-4, the proposition is that even while a union's representative authority is in force the employer may approach the employees directly, provided only that undue influence is not used. I do not think it could be safely assumed that this is correct But as the question does not require determination in this case it is better not to express a final opinion and to sound a note of warning only. 
The President's statement opens, rather than closes, a door through which a number of future litigants are likely to walk in search of answers. What does "approach employees directly" mean? The union may have authority to act as a bargaining agent in respect to the negotiation of a collective agreement, but as Chief Judge Goddard pointed out, the Act does not require employer neutrality. The employer has the basic freedom of speech. Clearly, an employee has a right to insist that the employer deal with his representative. But in the reality of many employment relationships, that insistence may be worn thin because of an imbalance of power. The employee's right to insist that the employer deal with a union representative may be more apparent than real.

On the other hand, the Appeal Court's signal may suggest a likelihood that the Courts may be willing to address, at least partially, a topic upon which the Employment Contracts Act remains largely silent, namely what are fair and unfair labour practices as between employers and employee representatives, including most obviously trade unions. As is well known, these questions are addressed directly in North American labour legislation which, like the ECA, is founded on the concept of the employment contract. Although the provisions of the ECA are silent in respect to unfair labour practices, the every day reality of employer and employee relations may require the Employment Court to deal with such issues within its equity and good conscience jurisdiction. This is, of course, purely a matter of the writer's speculation.

\section{Harsh and oppressive conduct}

Amongst other things, the union in Adams $v$ Alliance Textiles alleged that the new collective contract was obtained by harsh and oppressive behaviour, and that the contract was itself harsh and oppressive. Section 57 of the ECA is the governing provision. It prohibits two things. First, the section is directed against the use of harsh and oppressive behaviour, or undue influence or duress to obtain an employment contract. The question here is not whether the substance of the contract is harsh or oppressive, but whether the behaviour used to obtain the contract is unacceptable. Hence, a contract may be obtained in a harsh and oppressive way, even though the contract in its substance is not harsh and oppressive. Section 57 (4) empowers the Employment Court to set aside, either in whole or in part, a contract so obtained.

The second question is whether the contract itself is harsh and oppressive. Such a contract is perhaps likely to have been obtained by harsh and oppressive means. But nevertheless the potential holds that a contract may be harsh and oppressive, even though procured by means which the Court does not consider to be harsh and oppressive or undue influence or duress. Again, the Court is empowered to set aside, either wholly or in part, a harsh and oppressive contract. In setting aside a contract under Section 57, the Court is also empowered to award compensation to the aggrieved party.

The questions then are what constitutes a harsh and oppressive contract, and what constitutes harsh and oppressive behaviour or undue influence or duress? In his judgement in Adams $v$ Alliance Textiles, the Chief Judge made it clear that a harsh and oppressive 
contract must involve a serious inequality of exchange. The Alliance contract replaced a wage system under which employees were entitled to automatic wage increments according to length of service. The new contract related wage increases to the assessment of individual performance. Overtime and penalty payments were cut. Take home pay for the workers who were the applicants in the dispute were significantly reduced. The evidence indicated that other workers were able to maintain or even marginally increase their take home pay where their performance was highly regarded by the employer.

The employer's justification for the new contract was economic. The contract was, in the company's submission, necessary to ensure the continuing viability of the two plants. The design of the contract divided the workforce. Some workers could maintain or marginally improve their earnings. Other workers lost ground. While the Chief Judge identified the question as one of degree, contracts which significantly reduce the earnings of employees are not necessarily, by virtue of that reduction, harsh and oppressive contracts. The ECA is an Act the preamble to which identifies its chief purpose as the promotion of an efficient labour market. The adjustment of wages and conditions upwards and downwards is, according to the economic theory underlying the ECA, essential to the survival of the company and its employees.

The 1987 LRA was designed essentially to protect wages and conditions. That had been the design for labour legislation for the previous 100 years, and many are conditioned to see any reduction in take home pay to be harsh and oppressive. But under the ECA, significant adjustments downward will not automatically render a contract harsh and oppressive, particularly where the employer can show that the bona fide intent of the contract is to ensure the continuing viability of the company in a product or service market which is a highly competitive place. The question is simply whether the decision was made for the purposes of labour efficiency to enhance the company's competitiveness in the marketplace. Ultimately that is a question of degree that rests on a judgement as to whether the contract was exploitive. Section 57 of the ECA will not protect wages and conditions from being reduced except in the case where the contract is seen as exploitive in the extreme.

\section{Undue influence}

The next question has two parts. A contract may be set aside if an employer was in a superior position to the employee and took advantage of that position to obtain the contract. Undue influence arises where there is a special relationship between the parties involving confidence, control, domination or influence, such that the superior party is in a position to take advantage of the other party. If there is a special relationship between the parties, then the law creates the presumption that the superior party may have taken advantage of the other party in procuring a contract. The presumption means that the onus is on the superior party to prove that they have not taken advantage of the inferior party, and to show they have not exercised an unconscionable abuse of power and influence which directly procured the contract.

The special relationship has been held to exist in such client relationships as those entered 
into with lawyers, doctors, accountants, and other professionals. The list is not exhaustive, and it is over to a plaintiff or applicant to establish that such a special relationship exists if that relationship is not one which has been previously recognised by the law. In Adams $v$ Alliance Textiles, Chief Judge Goddard concluded that such a special relationship exists between an employer and its employees. However, the remainder of the full Court hearing the case, Judges Palmer and Colgan, disagreed. Their conclusion was that the employment relationship should not be added to the list which is invariably recognised by the Courts. In their view each employment relationship must be examined in the light of the particular facts, on a case by case basis. In the final analysis, the Chief Judge concluded that the union had not, in any event, shown that Alliance Textiles had taken advantage of its special relationship in procuring the new contract.

A word of warning should be noted. In the event that the Court concludes that such a special relationship exists, a critical issue becomes whether the employee has had independent advice in respect to entering into the employment contract. This point is of more obvious importance in respect to the relationship between, for example, a solicitor and client. If the solicitor and the client enter into a contract without the client receiving advice from a second and independent solicitor, then a presumption is drawn that the solicitor could have taken advantage of the client because of the client's lack of both knowledge of, and independent advice about the law.

In the relationship between employer and employee, there is often a reliance on the employer's greater knowledge of labour law. There may be circumstances where it is found that the employer is in a special relationship to the employee. The employer is in a superior position in regards to knowledge necessary to understand the contract and the effects of the contract, and that knowledge imparts the power which tempts abuse. A case may be subject to the argument that the employer has exercised undue influence on the employee where the employee has relied on the employer's advice in entering into a contract which significantly disadvantages the employee. In Adams v Alliance Textiles, the employer sponsored and financially supported an alternative organisation for the employees known as the Mosgiel Independent Thought Society (MITS). An employer-sponsored employees organisation is not a source of advice which could be considered independent where the issue of undue influence is raised.

\section{Economic duress}

The next question addressed in Adams $v$ Alliance Textiles was whether the contract had been secured through harsh and oppressive behaviour or duress. Of harsh and oppressive behaviour the Chief Judge said:

The behaviour complained of must strike the Court as reprehensible, as morally blameworthy and as meting out intolerable treatment. It will normally have elements of deliberation and unwarranted severity. Deceptive or misleading statements of the kind alleged and aggressive marketing by strong personalities do not strike me as amounting to the behaviour described in the subsection. 
The Chief Judge then went on to consider the question of duress. The Court decided that Alliance Textiles had threatened a legal lockout, and at one stage had legally locked out its employees. Without question, duress arises where one party to a contract illegally acts to coerce the second party to enter into the contract. However, the ECA establishes that strikes and lockouts intended to secure a new collective contract are legal. Section 68 of the Act provides as follows:

Where any proceedings under this Act relate to the participation of the defendant in a strike or lockout (being proceedings alleging a breach of contract on the part of the defendant or seeking the imposition of a penalty under this Act), the Tribunal or the Court shall dismiss that action or those proceedings if it is satisfied that the participation in the strike or lockout was lawful under section 64 of this Act.

The term "any" emphasises that any, if not all, proceedings will be dismissed if they relate to a lawful strike or lockout. Clearly an unlawful strike or lockout may qualify as economic duress, but the law establishes that economic pressure by way of strike or lockout is legitimate, even where the strike or lockout has dire social and economic consequences for those struck or locked out, and where the strike or lockout removes all practical options except consent to the terms insisted on by the initiator of the strike or lockout.

\section{Effectiveness of lockouts under the ECA}

In a pamphlet widely distributed to New Zealand households, the government essentially guaranteed that, under the ECA, wages could not be reduced by unilateral decision or action of an employer. The basis of this undertaking was the belief that workers were protected by provisions of the ECA which provided that, upon the expiry of a collective contract, employees are deemed to be on individual contracts based upon the expired collective contract. Further, the Act legalises strikes and lockouts in respect only to collective, and not individual contracts. The government's undertaking seemed initially to be supported in a number of early court cases under the ECA. Eventually, however, a loophole emerged.

If an employer seeks to negotiate a collective contract, then the employer may lock out employees in an effort to procure that collective contract. A collective contract is a contract applying to two or more employees. As an example, an employer might seek to renew a collective contract which has expired. The employees are on individual contracts under the terms of the expired collective contract. The employer has the right to lock out the workers. A second circumstance might involve a small employer with two employees who have never been covered by a collective contract. The employer may seek negotiations with these employees for a collective contract, and if necessary lock them out. Under either scenario, the employer may approach the employees and commence negotiations for a new collective contract. In either case the employer may legally lock out the employees. While the terms and conditions of their individual contracts may be retained by employees who successfully resist a lockout, the resources of the individual employee are seldom such that resistance can be sustained indefinitely.

The effectiveness of the lockout is greatly enhanced by the Court's interpretation given in Paul and Ors $v$ New Zealand Society for the Intellectually Handicapped Incorporated 
([1992] 1 ERNZ 65). In this case the employer imposed a partial lockout on its employees. The Court ruled that despite the inferences to be drawn from the term "lockout", the employer could maintain day to day operations while reducing wages and conditions to less than those provided in the employees' individual contracts. Hence, the lockout did not involve locking the doors to keep employees out. The employer did not suffer from closing the business in order to force employees to accept reductions as a part of a new collective contract. Pressure was applied to employees by "locking them out" from particular conditions of their individual contracts (based on the expired collective) which the employer sought to exclude from the new collective contract.

While there were outcries to the effect that the Court's approval of the "partial lockout" as a tactic was unfair, those who cry out overlook the fact that the "go slow" is the employees' counterpart to the employers' "partial lockout". The employees' counterpart means that wages are paid in full but the employer's output is cut by the employees. In the case of the total strike or lockout all profits usually cease on the employer's side, and that is counterbalanced by the fact that all wages cease on the employees' side. Partial lockouts and go slows are iniquitous insofar as they impose economic damage unequally on the parties. Nevertheless, both weapons are part of an arsenal available to the parties who participate in a system which is now designed under the ECA to be driven by economic power rather than equity.

\section{Utilisation of non-union employees}

The partial lockout was initially identified by many as one of the evils of the ECA, but in fact the law relating to lockouts was not changed by the ECA. The lockout and partial lockout were available in the same forms under the LRA. There are, however, reasons why the lockout may be more effective under the ECA, and why the strike may be less effective. Under the ECA the employer can replace locked out or striking workers with temporary workers, who may be either non-union workers or workers belonging to a competing union. Whether locked out or striking workers could be dismissed and permanently replaced during a lawful strike is a question answered in the affirmative under the common law. Whether the dismissals could be justified under the personal grievance procedures is a different question.

The demotion of an employee with managerial responsibilities who participated in a strike and refused to sign an undertaking not to repeat her action was held to be substantively justified in Parish v Capital Newspapers Ltd ([1992] 2 ERNZ 302). A worker who participates in a strike has clearly indicated an unwillingness to work under the terms of the collective contract. Such an indication is clearly a repudiation of the contract. On the other hand, strikes over collective contract renewal are legal. Does the Act therefore legalise this form of repudiation? If it does not, then strikers may be permanently replaced. The bargaining imbalance stems in part from the fact that in an economy with continuing high unemployment, the employee is unlikely to replace his or her employer, whereas the employee is often easily replaced. 
The utilisation of non-union labour or labour from competing unions not only enhances the effectiveness of the lockout, it also undermines the effectiveness of the strike. In Unkovich $v$ Air New Zealand Limited ([1993) 1 ERNZ 526), the employer made 159 employees redundant. The employees were employed in the employer's catering section which was experiencing increased competition at the Auckland air terminal. The employees were replaced by independent contractors. Unkovich had initially argued that these were not independent contractors, but in effect employees of Air New Zealand. The argument did not succeed. The dismissal of the employees was held to be substantively justified, although Air New Zealand failed to handle the dismissals in a procedurally fair manner. The case illustrates that employees may be undercut by independent contractors who provide inferior wages and conditions for their own employees. The use of redundancy thus becomes another weapon in the bargaining armoury of the employer. Either wages and conditions will be reduced, or workers will be made redundant and replaced by contractors. The weapon is enhanced under the ECA because the competing independent contractors can utilise cheaper non-union labour.

\section{Marketing the trade union}

What Adams $v$ Alliance Textiles confirms is that the ECA allows for a battle over the hearts and minds of employees. The ECA does not require employer neutrality in respect to the employees' decision as to whether a union is to be authorised as their representative. A wide range of tactics may be used by the employer to influence the decision, including the sponsorship of alternative employee organisations. The employer is prohibited from exercising undue influence against an employee's decision to join and remain in a trade union. On the other hand there appears to be little prohibition against the employer taking actions which render the union ineffective in its representation of the employee in bargaining over a collective contract. The employee is protected if he or she decides to join the union, but the union may be rendered so ineffective that there is no reason to join.

The personal grievance procedures are one aspect of the ECA clearly designed on the basis of equity rather than the efficient operation of the labour market. The procedures themselves are in large measure the same as those under the LRA. The critical changes have been the extension of coverage to all employees throughout the country, and the provision of adjudication, generally after mediation, as the last avenue for disposing of a grievance.

Adjudication is a relatively formal legal process. As a consequence, a significant majority of parties who appear before the Employment Tribunal are now represented by lawyers or industrial consultants. Under the ECA, the unions have lost significant ground in terms of representing employees in personal grievance proceedings. Under the LRA union membership was a required condition for access to the personal grievance procedures. It was a significant reason for joining a union. Under the ECA, not only has the statutory support for the union as a representative in collective bargaining been abolished, but the one unique service unions provided their membership - personal grievance representation - has been let out to tender. Marketing the trade union in the market economy is not a task assisted by the ECA. 


\section{Conclusion}

The history of organising labour in less civilised countries like the United States is punctuated with frustration that often exploded into civil disturbance. Scenes of death and destruction of property were vivid elements of early American labour history before rules for regulating unfair labour practices between management and labour became a feature of United States labour law, initially in the 1930s. The labour legislation of the earlier period was characterised by the same silence regarding unfair labour practices which may come to haunt the ECA. This assertion may seem far fetched at this point of time in New Zealand, but we seem intent on replicating many other of the less fortunate aspects of life in America. The fundamental impact of the ECA on labour law is to abolish the legal status of trade unions, to abolish the statutory assistance formerly given to the union as a bargaining agent in collective bargaining, and to diminish the role of the union as a representative of employees in disputes and personal grievances.

The terms of reference for this paper were to comment on the effect of the ECA on the law. The changes in the law have generated a wide range of social and economic changes beyond the scope of industrial relations. But the evidence is mounting that the unions are suffering significantly under the Act. Harbridge and Hince predicted as follows in 1993:

However, if the Employment Contracts Act continues as the central labour statute, with its emphasis on individual rather than collective relationships, there can be no doubt that further, probably substantial, membership losses will occur. (Harbridge, 1993:234)

Trade union fortunes may again rest on the outcome of an election just as they did in 1990, but a political restructuring is unlikely to succeed to the extent of the political coup achieved by employers with the enactment of the ECA. There will not be a return to a system of industry wide awards, and there will not be a return to compulsory unionism.

The union is now an incorporated society, and just like any other corporate body may find itself floating belly up in the market place. However, the fortunes of the economy are turning. New Zealand with its reliance on an export economy will have a number of unions strategically placed to take advantage of the upturn in economic fortunes. It can be expected that the rugged and robust approach of some employers to union bargaining representatives will be reciprocated in the near future by employees concerned that their compatriots return to the union fold. "Undue influence" is a term which does not exclude the exercise of "due" influence by employees upon a fellow employee. In the past employees have been remarkably inventive in this regard.

Where there is wealth to be shared with the employees, that wealth will be apparent. Employees in strategically placed industries will act in concert to ensure their fair share. Their employers will become "born again" government interventionists, and the government will be keen to once again intervene. The object will not be to reintroduce compulsory arbitration or unionism. The desire will be for legislation which does not determine outcomes between unions and employers, but which sets in order the manner in which unions and employers relate to one another, and respect one another's rights within the 
market place. However, the Government will have been elected under the MMP electoral system, and the problem will not be fixed as in the past by the overnight dash of the legislative draftsmen's pen. The industrially vulnerable - wealthy employers, and employees not strategically placed within the economy - will be odd fellows waiting together for a legislative train which may be some time in arriving.

\section{Reference}

Harbridge, Raymond (1993), Employment Contracts: New Zealand Experiences, Wellington: Victoria University Press. 


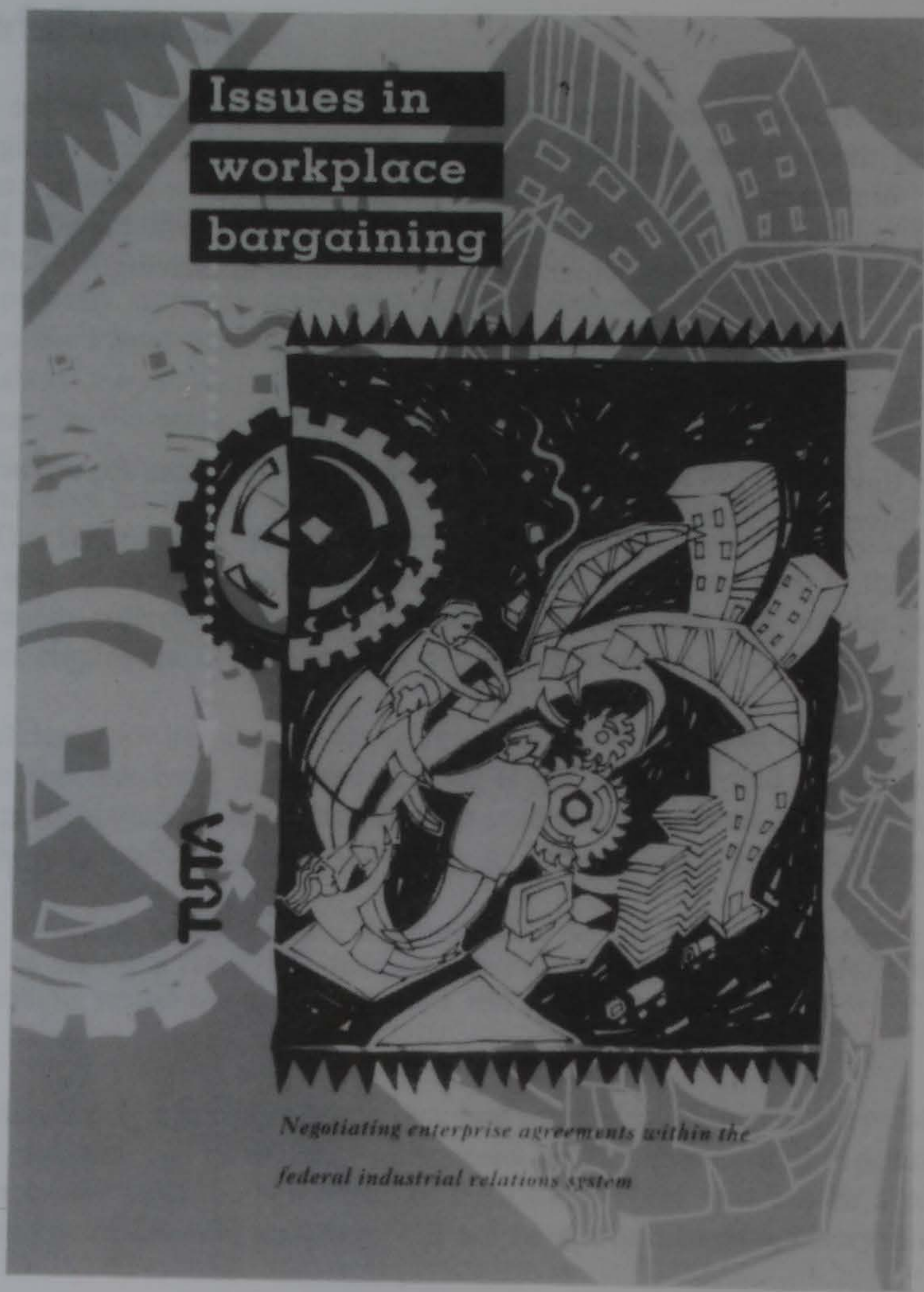

Australia's Trade Union Training Authority (TUTA) has released a major publication on enterprise bargaining titled "Issues in Workplace Bargaining".

According to the publishers, it is the most comprehensive and easy-to-read analysis of enterprise bargaining available and, in the words of ACTU President Martin Ferguson who contributed the publication's foreword, it will make a "substantial contribution" to the debate on the subject.

"Issues" explains how enterprise bargaining developed, how it works, what agreements should cover and how to make agreements work.

Issues has a recommended retail price of $\mathrm{A} \$ 50$ and is available by mail order from TUTA's head office (PO Box 12365, A'Beckett Street, Melbourne 3000). 